DOI: $10.31866 / 2616-759 X .4 .1 .2021 .234239$

Удк 792.081:7.079(100)(477)

\title{
МІЖНАРОДНИЙ ФЕСТИВАЛЬ ЖІНОЧИХ МОНОДРАМ «МАРІЯ» ЯК ДІАЛОГ КУЛЬТУР
}

\section{Ольга Шлемко}

кандидат мистецтвознавства, доцент, заслужена артистка України; e-mail: olgateren@ukr.net; ORCID: 0000-0002-3431-4521

Національна академія керівних кадрів культури і мистецтв, Київ, Україна

\begin{abstract}
Анотація
Мета дослідження - виявити генезу та динаміку сучасного розвитку Міжнародного фестивалю жіночих монодрам «Марія», визначити його місце і роль у системі театрального фестивального руху України та Європейського Співтовариства, з'ясувати специфіку організаційної, мистецької та соціокультурної складової фестивалю. Методологія дослідження полягає в застосуванні системного, театрознавчого та культурологічного підходів, а також низки методів: культурноісторичного, класифікації, проблемно-хронологічного, спостереження, порівняння. Наукова новизна дослідження полягає в його системності, комплексності, здійсненні класифікації театральних фестивалів і ґрунтовному аналізі складових фестивалю «Марія», з'ясуванні його феномену. Висновки. Міжнародний театральний фестиваль жіночих монодрам «Марія» - єдиний в Європі жіночий фестиваль моновистав, територія діалогу та полілогу, успішного проєкту, який об'єднує мисткинь різних країн і різних культур, територія культурної дипломатії, наповнена певними смислами, енергіями. Репертуар фестивальних моновистав відзначається різножанровістю, високим професіоналізмом виконавців, сучасним режисерським прочитанням. Це організований на високому рівні щорічний культурномистецький форум, у межах якого відбуваються науково-творчі конференції та круглі столи, майстер-класи, тематичні виставки, творчі дискусії, презентації книг з теорії та історії театру. Фестиваль сприяє інтеграції українського театру до європейського культурного простору, надає глядачам можливість побачити кращі моновистави за участі українських і зарубіжних виконавців.
\end{abstract}

Ключові слова: моновистава; монодрама; жіночий; акторка; фестиваль «Марія»; міжнародний; Лариса Кадирова

\section{Постановка проблеми}

Стрімкий розвиток театрального фестивального руху в Україні у найрізноманітніших проявах змушує науково осмислити це мистецьке та соціокультурне явище. Особливе місце у фестивальному русі посідає Міжнародний фестиваль жіночих монодрам «Марія», а тому його системне та комплексне дослідження сприятиме ефективнішому використанню потенціалу фестивалю, 
Вісник Київського національного університету культури і мистецтв.

Серія: Сценічне мистецтво

подальшому розвитку жанру моновистав і в цілому театрального мистецтва України.

\section{Аналіз досліджень і публікацій}

Теоретичне обґрунтування жанру моновистави та їі сценічного втілення стало предметом наукового осмислення М. Євреїнова, В. Яхонтова, С. Юрського, Н. Кримової, Д. Катишевої, Р. Колосова, І. Волицької, Ж. Бортнік, Т. Джурової, У. Рой та ін.

Уперше теоретичне обґрунтування монодрами здійснив 1908 р. М. Євреїнов у своїй доповіді «Вступ в монодраму». Митець, пророкуючи монодрамі найближче майбутнє, розумів під цим поняттям «такого роду драматичну виставу, у якій світ, що оточує дійову особу, є таким, яким сприймає його дійова особа в будьякий момент її сценічного буття» (Євреїнов, 1909, с.15). На думку М. Євреїнова (1909, с.15), «наріжний камін монодрами - переживання дійової особи на сцені, що обумовлює тотожне переживання глядача, який через цей акт переживання стає так само дійовою особою». Однак для цієї мети на сцені має перебувати лише один суб'єкт дії. Він вважав за необхідне відмовитися від традиційних декорацій, натомість використовувати сучасні швидкозмінні декорації, технічні засоби освітлення, грим, міміку тощо. «Образно кажучи, у предметах, що перебувають на сцені, має ніби циркулювати кров дійової особи і навіть найтвердіший камінь не має мовчати поряд з дійовою особою», - зазначає М. Євреїнов (1909, с.21).

Оскільки у назві досліджуваного фестивалю присутнє поняття «монодрама», то важливо з'ясувати його значення. У деяких джерелах поняття «монодрама» подається як симбіоз театрознавчої та літературознавчої термінології, а тому його зараховують як до сценічної, так і до літературної творчості. Монодраму можна розглядати і як різновид психодрами, тобто як психотерапевтичний метод. Монодрама може слугувати також і драматургічною основою для моновистави. Водночас в Енциклопедії Сучасної України наведено визначення монодрами:

«[...] музично-сценічний твір, що виконується одним солістом або драматичним актором [...] Походить від театру доесхілівськоїдоби (Феспід, Фрініх), де один актор зображав різних персонажів, змінюючи маски й костюми. Художній принцип монодрами полягає у сповіді-монолозі іï героя. У монодрамі здебільшого бере участь один персонаж, якщо $€$ інші, то вони до активного розвитку драматичних подій не залучені». (Толошняк, 2006)

За визначенням А. Паві (2006, с.258), монодрама - «це п'єса з одним персонажем або принаймні з одним актором (який виконує декілька ролей). П'єса вибудовується навколо однієї особи з демонстрацією її внутрішніх мотивацій, суб'єктивних поглядів і сентиментів».

Інтерес до монодрами тривав і на початку XXI ст., коли вона «стала об'єктом для теоретичної та критичної рефлексії, викликавши особливе зацікавлення театрознавців, психологів, соціологів тощо. 
Ії̈ розглядали як театральний, психотерапевтичний, музичний жанр, художньо-комунікативну та рецептивну стратегію, механізм перетворення театру, форму суб'єктивності, особливий погляд на дійсність та мистецтво тощо - все, що передбачає втілення, демонстрацію чи розгляд проблеми крізь призму свідомості "єдиного суб'єкта дії"». (Бортнік, 2015, с.122-123)

Отже, «монодрама» - це досить широке і неоднозначне поняття. Тож не варто вживати синонімічно такі поняття, як «монодрама» і «моновистава». Згадана термінологічна плутанина свідчить про те, що для означення театральної вистави з однією дійовою особою слід використовувати цілком однозначний термін «моновистава». Тому було б доцільно уточнити назву фестивалю «Марія» за допомогою заміни слова монодрама на моновиставу.

Діяльність театральних фестивалів в Україні осмислювали у своїх наукових розвідках О. Доманська, О. Литовка, М. Близнюк, Т. Зубенко, М. Юдов, А. Вічна, Г. Хрома та ін. Про Міжнародний театральний фестиваль жіночих монодрам «Марія» писали, зокрема, Л. Гончаренко, Д. Дроздовський, В. Заболотна, Л. Ільєнко, С. Максименко, А. Підлужна, А. Небельська, Е. Овчаренко, Л. Олтаржевська, О. Сливка, Т. Поліщук, С. Шашко. Цікаво, що у 2013 р. осмислити згаданий фестиваль на шпальтах наукового видання зробила спробу його організаторка Л. Кадирова, яка більше уваги приділила спогадам про свої ролі у виставах за творами М. Гоголя, А. Чехова, Г. Маркеса (2013, с.84-94). Саме цим авторам були присвячені наукові конференції, що відбувалися в межах фестивалю «Марія». Однак ґрунтовна, узагальнювальна наукова праця про цей мистецький фестиваль досі відсутня. Саме тому виникла необхідність у межах наукової статті осмислити феномен Міжнародного театрального фестивалю жіночих монодрам «Марія».

Метою дослідження $є$ виявлення генези та динаміки сучасного розвитку Міжнародного фестивалю жіночих монодрам «Марія», визначення його місця і ролі в системі театрального фестивального руху України та Європейського Співтовариства, з'ясування специфіки організаційної, мистецької та соціокультурної складової фестивалю.

\section{Виклад основного матеріалу}

Фестивальний рух в Україні після проголошення її незалежності набуває все більших обертів. Загалом

«фестивальний рух є показником і своєрідним каталізатором інтенсивності та якості мистецького життя будь-якої країни, найбільше у розвинутих європейських державах. Фестивалі, як засвідчує світовий та український досвід, що визначають напрямки розвитку мистецтва, продукують нові ідеї, відкривають нові безмежні обрії творчої діяльності. Фестиваль - це не тільки свято та насолода (франц. festival - свято, від лат. festivus - веселий святковий), а й своєрідний механізм регулювання та корекції естетичних смаків, поглядів, формування нових ідеалів. Це також перевірка практикою новацій, визна- 
чення пріоритетів і пошук неторованих шляхів розвитку театрального мистецтва та культури». (Литовка, 2013, с. 112)

Театральні фестивалі в Україні стали невід'ємною складовою культурномистецького життя, важливим чинником залучення українського театрального мистецтва і в цілому України до світового культурного простору. Функції театрального фестивалю: творча, соціальна, комунікативна, пізнавальна, інформаційна, рекреаційна, розважальна, ціннісно-орієнтована, просвітницька, естетична.

Моновистава $€$ одним із найскладніших жанрів театрального мистецтва і важливою складовою культурного простору України. Особливе місце у фестивальному русі посідає Міжнародний фестиваль жіночих монодрам «Марія», що $€$ унікальним інформаційно-комунікативним каналом сучасного театрального процесу.

Моновистава - це вищий пілотаж акторської майстерності, оскільки актор може покладатися лише на себе, на власний досвід і майстерність. Жанр моновистави вимагає від виконавця чи виконавиці максимального самовираження, зібраності, зосередженості, активізації всіх своїх психофізичних сил, уміння вести діалог із залою. Опинившись віч-на-віч з глядачем, він чи вона не можуть сховатися ні за своїх партнерів, ні за звичні для звичайної вистави декорації, бутафорію, реквізит. Для того щоб мати право вийти один на один перед глядачем, актор чи акторка повинні мати достатній сценічний досвід і чітку громадянську позицію.

Моновистава - це не просто монолог актора, а ціле життя однієї людини, яка взаємодіє із всесвітом сам на сам перед глядачем, прискіпливо досліджує природу вчинків свого персонажа, шукає відповіді на вічні питання буття. Специфіка моновистави дає змогу сценічному твору змінюватися та розвиватися разом із художнім і життєвим досвідом свого виконавця. Виконання моновистави стає свідченням сформованого професіоналізму та високої майстерності артиста.

Ініціатором і директором Міжнародного театрального фестивалю жіночих монодрам «Марія» $€$ народна артистка України Лариса Кадирова. Це єдиний фестиваль жіночих монодрам на теренах Європи. Започатковано фестиваль 2004 р., саме тоді, коли відзначали 150-річний ювілей від дня народження геніальної артистки Марії Заньковецької.

Л. Кадировій пощастило протягом 22 років більше ніж 600 разів утілювати образ Марії Заньковецької в однойменній виставі Львівського академічного драматичного театру ім. Марії Заньковецької. Геніальна артистка стала для Л. Кадирової яскравим прикладом служіння національній сцені, своєму народові. Тож згаданий фестиваль «Марія» було названо на честь Марії Костянтинівни Заньковецької, а відбувається він щороку в жовтні, оскільки 4 жовтня 1934 р. вона відійшла у вічність. Л. Кадирова так пояснює виникнення задуму фестивалю «Марія»:

«Зазнавши в ролі Заньковецької дивовижної вдячності, любові, таланту, існуючи із цією особистістю стільки часу і оселивши її в своєму серці назавжди, я хотіла, щоб пам'ять про неї жила довго, щоб лунало 
ім'я Марія, потім емоційно воно зливалось з ім'ям Діви Марії, набувало такого об'ємного звучання і ставалося те диво мистецтва, пам'яті вдячності». (Підлужна, 2013, с.22)

Перший фестиваль «Марія» відбувся в приміщенні Київської академічної майстерні театрального мистецтва «Сузір'я» і розпочався моновиставою Л. Кадирової «Посаг кохання» за Г. Г. Маркесом. Фестивальні вистави показали представниці України, Білорусі, Польщі, Росії. Своєрідним епілогом фестивалю став круглий стіл «Актриса» («Виміри акторської майстерності сучасної Актриси»), де порушувалися проблеми, що виникають у жінки-акторки в театрі й особистому житті, про шляхи самореалізації талановитих мисткинь.

Усі наступні фестивалі «Марія» відбувалися в приміщенні Національного академічного драматичного театру ім. Івана Франка. Традиційно фестивальні моновистави відбуваються на Камерній сцені ім. Сергія Данченка, а інші фестивальні заходи у фоє та в інших приміщеннях театру. Камерна сцена, неначе збільшувальне скло, виявляє внутрішній стан актора, його духовність і громадянську позицію. Л. Кадирова зазначає:

«Камерна сцена прояснює людину наче рентгеном, виявляє мотиви вчинків, слів, жестів, просто талант актора, його культуру у ставленні до професії, його вміння синтезувати власний стиль з життєдайною енергією. Камерна сцена глибоко пронизує простір відчуттям дисгармонії сучасного світу та утворює власний театральний космос. Камерна сцена - простір, де перетинаються інтереси драматурга й актора...». (Кадирова, 2013, с.93)

Фестиваль «Марія» $є$ благодійний, а тому вхід на всі вистави для глядачів вільний. Слід наголосити, що фестиваль великою мірою відбувається завдяки підтримці генерального директора - художнього керівника цього театру М. Захаревича, який до того ж бере активну участь у конференціях і круглих столах. Допомагав у організації фестивалю і колишній художній керівник цього ж театру Б. Ступка. Так, під час проведення фестивалю у 2008 р. М. Захаревич значився як художній керівник фестивалю, а Б. Ступка - його директор. Фестиваль для столичного театру ім. І. Франка є унікальним майданчиком для презентації свого мистецтва та багатої історії.

Інтегрованість Л. Кадировоїу різні форми мистецько-культурного життя в Україні, громадсько-культурна діяльність, широкі контакти з багатьма театральними митцями, письменниками, організація різноманітних мистецьких заходів і безпосередня участь у них сприяли влаштуванню фестивалю «Марія». Громадськість знає Л. Кадирову як президента Міжнародної благодійної організації «Міжнародний інститут театру» (Український центр) - з 1993 р.; заступника голови Національної спілки театральних діячів України (1992-2000рр.); голову правління благодійної організації «Шевченківський фонд XXI»; організаторку та голову журі Міжнародного фестивалю античного мистецтва «Боспорські агони» (від 1998 р.); голову художньої ради Національного університету «Києво-Могилянська академія». Артистка була також у складі Комітету з Національної премії України імені Тараса Шевченка, має досвід участі в різноманітних міжнародних театральних фестивалях (Йорданія, Нідерланди, Німеччина, Чехія, Франція, США та ін.). 
Вісник Київського національного університету культури і мистецтв. Серія: Сценічне мистецтво

Однак без професійної команди організувати фестиваль такого рівня неможливо. Незмінним помічником Л. Кадирової в організації та проведенні фестивалю «Марія» є театрознавець Алла Підлужна, яка, по суті, здійснює інформаційноаналітичний супровід фестивалю, бере активну участь в обговоренні вистав, дискусіях на наукових конференціях і круглих столах. Також чимало зусиль щодо створення науково-мистецької атмосфери докладає літературознавець Д. Дроздовський, який, зокрема, допомагав в організації науково-мистецької конференції «Діалог культур».

Л. Кадирова не лише організатор фестивалю моновистав, а й безпосередня виконавиця семи моновистав, створених у співдружності з різними режисерами. Усі її героїні є самотніми, але сильними та щасливими. Тож артистка бере участь у фестивалі «Марія» не лише як його організаторка й ідейний натхненник, а й як артистка. Моновистави виникли в артистки внаслідок недостатньої зайнятості в репертуарі Національного академічного драматичного театру ім. Івана Франка, нестримного бажання творчої самореалізації, а також прагнення проявити свої організаторські здібності, опанувати європейський культурний простір.

Створення фестивалю «Марія» мало «на меті популяризацію кращих світових здобутків виконавської майстерності актрис, плекання, культивування та репрезентацію можливостей універсальної мови театру, сприяння активній інтеграції українського театру до світового театрального процесу» (Овчаренко, 2019).

3 кожним роком фестиваль набуває все більшої популярності, істотно розширилася його географія, яка охопила не тільки чимало українських міст, а й низку зарубіжних країн: Австралію, Азербайджан, Алжир, Болгарію, Велику Британію, Вірменію, Грузію, Єгипет, Ізраїль, Іспанію, Італію, Литву, Мексику, Німеччину, Норвегію, Пакистан, Польщу, Португалію, Росію, Словаччину, Туреччину, Францію, Чехію, Японію. Концепція фестивалю передбачає запрошення до участі в ньому кращих акторок з України та зарубіжних країн.

Учасниці фестивалю в процесі творчого спілкування стають однією театральною родиною. На фестивалі панує творча атмосфера, свято єднання, діалог культур, різних напрямів і жанрів, творчих підходів, естетик, відбувається спілкування учасників, обмін досвідом. Театральні митці та глядачі мають можливість також ознайомитися з різножанровими виставами, тенденціями розвитку театру, різними театральними напрямами. Душею фестивалю вважають його засновницю Л. Кадирову.

У 2005 р., тобто через рік після заснування фестивалю, до Києва приїхали представниці Білорусі, Єгипту, Норвегії, Польщі. Україну на фестивалі представляли Л. Кадирова з виставою «Посаг кохання» Г. Г. Маркеса і Н. Половинка з виставою «Квітка-Невіста». Наприкінці фестивалю відбувся круглий стіл «Виміри акторської майстерності сучасної Актриси», а у фоє Національного академічного театру ім. І. Франка експонувалася виставка «Актриса», де учасники та гості фестивалю мали можливість ознайомитися з матеріалами з фондів музею Марії Заньковецької.

Участь у наукових конференціях та круглих столах беруть відомі вчені, театральні діячі з України та зарубіжних країн (див. рис. 1). Так, у роботі Міжнародної науково-мистецької конференції «Магічний вплив Гоголя на світовий та 
український культурні процеси» (2009) брали участь гості з Італії: професори Римського університету Санто Граччотті й Оксана Пахльовська; «Магія А. П. Чехова» - академік НАН України Микола Жулинський, професори Жаклін Кар Філіпс і Маргарет Сіріл Коллі (Велика Британія); «Вплив магічного реалізму Г. Маркеса на світовий та український культурні процеси» - професори Джеральд Мартін (Велика Британія), Чен Ксю (Китай), Ольга Реаль-Нахарро (Мексика), Жан Франко (США). Науково-мистецькі конференції відзначалися високим науковим та організаційним рівнем. Якщо ж не вдавалося досягнути належного наукового рівня як, наприклад, під час проведення круглого столу «Сучасні виміри акторської майстерності» (2006), то він ставав майданчиком для цікавих дискусій.

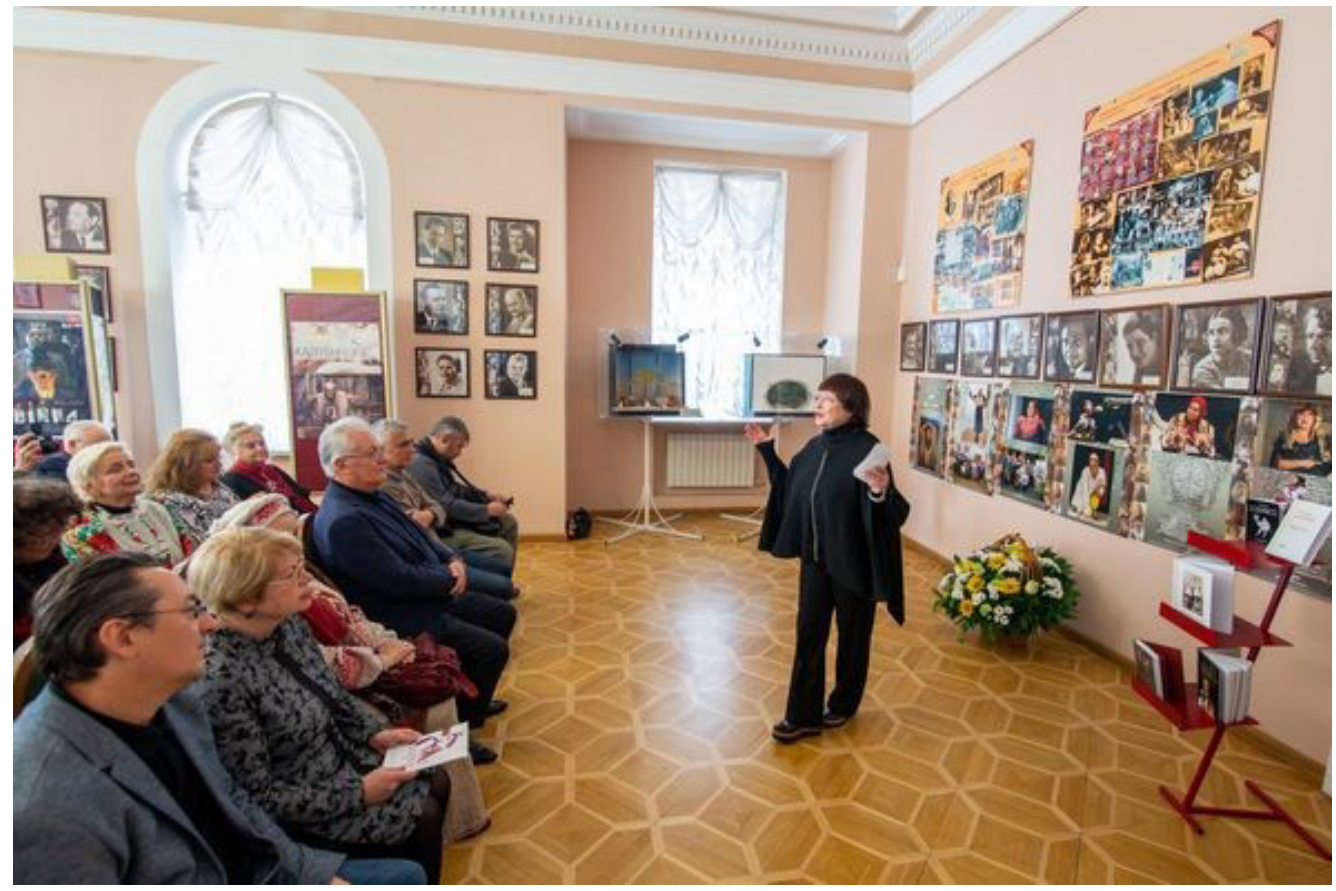

Рис. 1. Лариса Кадирова виступає перед учасниками науково-мистецької конференції «Магія акторства. Діалог культур». Київ, 07.10.2018 p.

Останній XVI Міжнародний театральний фестиваль жіночих монодрам «Марія» відбувався протягом 4-9 жовтня 2019 р. Проведенню цього мистецького заходу у 2020 р. завадила пандемія коронавірусу. Афіша фестивалю свідчила, що він проходить під егідою Міністерства культури України, Національного академічного драматичного театру ім. Івана Франка, Міжнародної благодійної організації «Міжнародний інститут театру» (Український центр) та за сприяння Інституту літератури ім. Т. Г. Шевченка, Музею Марії Заньковецької, відділу Музею театрального, музичного і кіномистецтва України, Благодійного фонду «Наш дім Україна». 
На суд глядача було винесено різножанрові вистави, серед яких найбільше з репертуару Національного академічного драматичного театру ім. Івана Франка: «Morituri te salutant» за новелами В. Стефаника; «Земля» за О. Кобилянською; «Стара жінка висиджує» Т. Ружевича та «Не плачте за мною ніколи» М. Матіос Лариса Кадирова (див. рис. 2 і 3); «Момент кохання» за В. Винниченком - Євген Нищук. Серед виконавців інших українських моновистав Анжеліка Гирич і Поль Манонідз (французький актор) - «Я кохаю» (Київський академічний театр юного глядача на Липках); Лідія Данильчук - «Білі мотилі, плетені ланцюги...» за В. Стефаником (Львів); Мирослава Солук, Ірина Швайківська - «Картка любові» Р. Горака (Львів); Олександра Тарновська - «Монолог актриси», інсценізація С. Павлюка (Херсон); Марина Проценко - «За надмірну любов» М. Матіос (Дніпро); Петро Миронов - «Чорний птах з білою відзнакою» за В. Стусом (Київ). Порадували глядача й зарубіжні виконавиці: Олена Кюн, Ярослава Горобей, Віка Левовська - «Німеччина-Сендвіч» С. Фурер, К. Бендінг, О. Кюн (Німеччина, Кельн); Марта Погребні - «Солодка Даруся» М. Матіос (Польща, Зелена Гура); Галина Дзягілєва - «Обраниця» за О. Пушкіним (Білорусь, Мінськ). Отже, не всі фестивальні вистави були моновиставами. До того ж участь у фестивалі також акторів-чоловіків свідчить, що цей мистецький захід перестає бути суто жіночим. Певним сюрпризом стала пластична вистава «Спокушені спрагою» з Кривого Рогу, що продемонструвала глядачам оригінальні невербальні виражальні засоби.

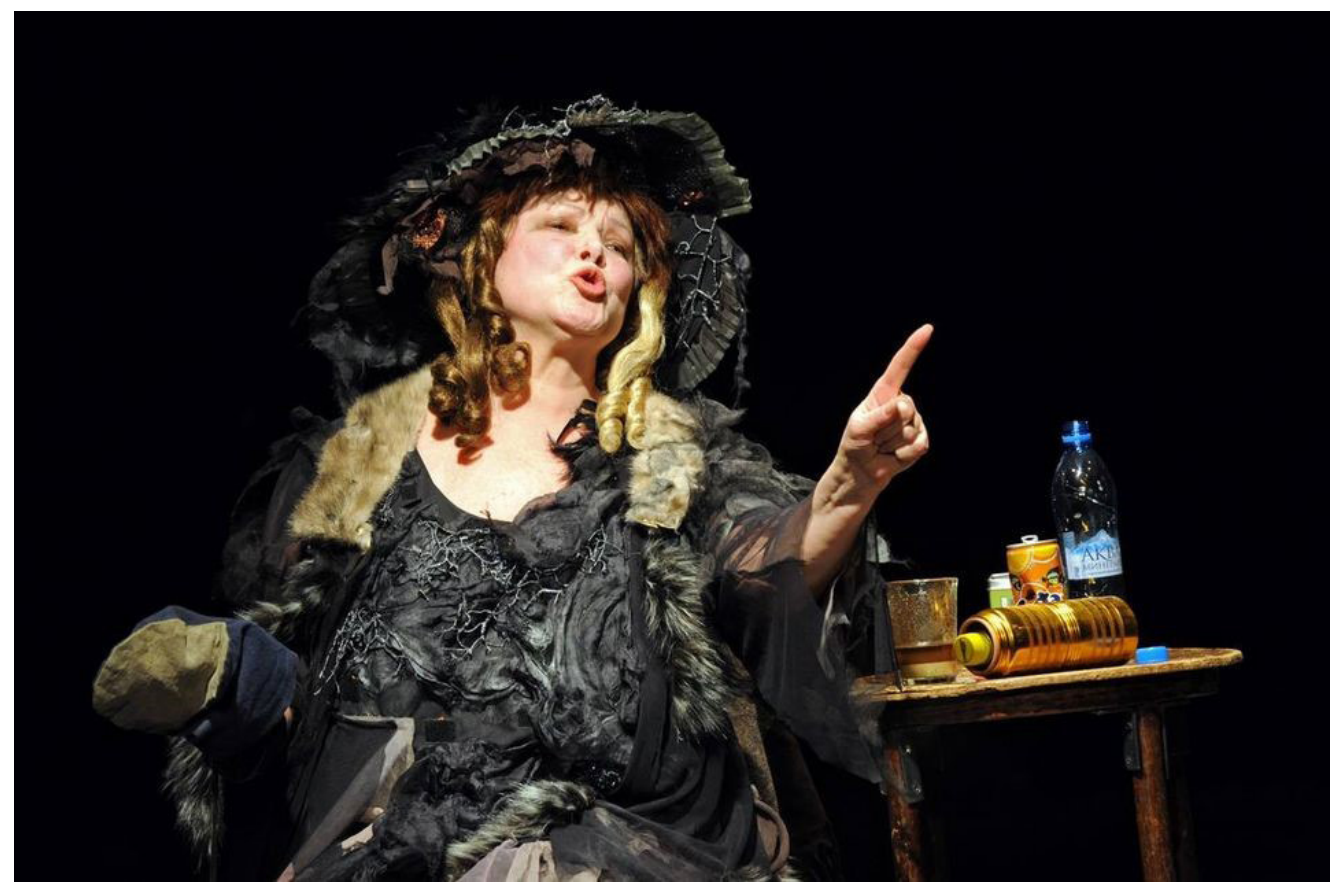

Рис. 2. Лариса Кадирова у моновиставі «Стара жінка висиджує» Т. Ружевича. Режисер - Збігнєв Хшановський. Київ, 05.10.2018 p. 


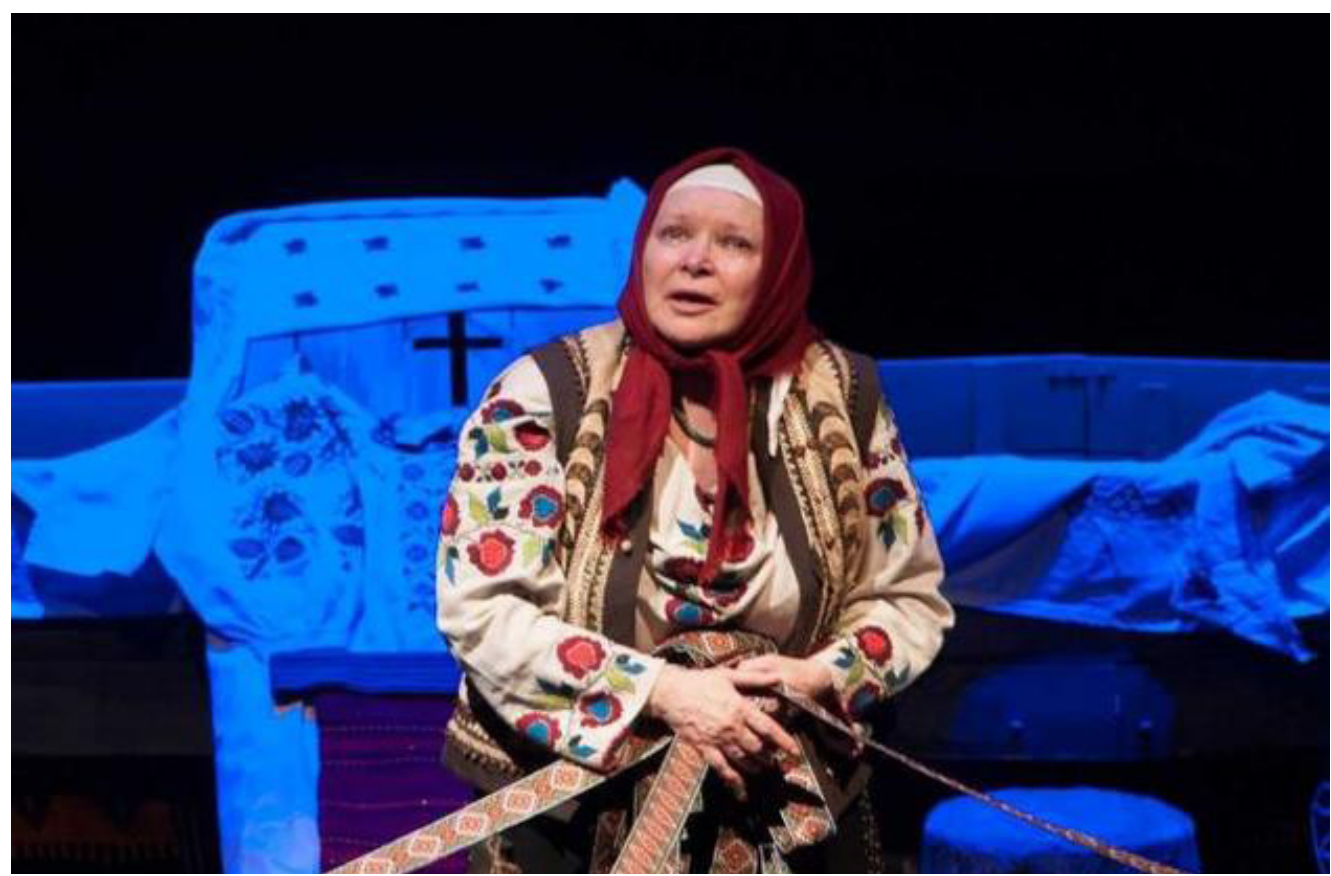

Рис. 3. Лариса Кадирова в ролі Юстини у моновиставі «Не плачте за мною ніколи» М. Матіос. Режисура та сценографія Сергія Павлюка. Київ, 2019 р.

Незначну кількість представниць зарубіжних країн (Білорусі, Німеччини та Польщі) пояснюють недостатнім фінансуванням цього форуму. Зі слів Л. Кадирової довідуємося, що на цей фестиваль Міністерство культури не виділило жодної копійки. Тож через недофінансування значна частина закордонних гостей на фестиваль не приїхала (Поліщук, 2019). Вартість проїзду учасників фестивалю здійснюється їхнім коштом, а вартість перебування в Києві двох учасників моновистави - за кошти організаторів фестивалю.

Особливість фестивалю жіночих монодрам полягає також у тому, що артистки та гості «відчувають себе "органічною часткою живої фестивальної інфраструктури": беруть участь у перегляді вистав, творчих зустрічах, дискусіях, засіданнях круглого столу, відвідують музеї, тематичні виставки, презентації, майстер-класи, вечірній театральний клуб. Тим фестиваль сповідує прогресивну європейську ідею театру як творчого, дослідницького, експериментального центру» (Гончаренко, 2017). Хоча фестиваль не конкурсний, але моральну, духовну, естетичну винагороду отримують усі. Найкращою нагородою для його учасників є сама участь у фестивалі. Мобільність моновистави проявляється в тому, що вона, як правило, має мінімум декорацій, а тому її учасники можуть безболісно гастролювати, брати участь у фестивалях.

Для ґрунтовного комплексного дослідження доцільно створити ефективний інструмент у вигляді класифікації фестивалів, що враховуватиме феномен фестивалю «Марія». 
Здійснимо диференціацію театральних фестивалів за такими ознаками:

- організаційно-територіальним статусом: міжнародні, всеукраїнські, регіональні;

- фаховим статусом: професійні, аматорські;

- формою проведення: стаціонарні, мобільні;

- місцем проведення: місто або інший населений пункт;

- локацією: приміщення театру або іншої установи, просто неба;

- періодичністю: одноразові, щорічні, один раз на два роки;

- тривалістю проведення: довгострокові (більше одного місяця), середньострокові (від одного тижня до одного місяця), короткострокові (від одного дня до одного тижня), а також перманентні, пов'язані насамперед із запровадженням обмежувальних протиепідемічних заходів (карантину) у зв'язку з пандемією коронавірусу;

- форматом проведення: камерний, моновистав, фестиваль-лабораторія, різноформатний;

- формою змагальності: фестиваль-конкурс, фестиваль-огляд, фестивальрепрезентація;

- жанрово-репертуарною палітрою: комедійні, музичні, різножанрові;

- способом залучення глядача: благодійні, платні;

- за джерелами фінансування: державні (бюджетні), приватні (меценатство, спонсорство), державно-приватні;

- статевою та віковою ознакою: жіночі, дитячі, молодіжні, студентські, дорослі;

- іменним статусом: персоніфіковані (присвячені видатній особі), присвячені знаменній події, акторській грі та режисурі, національним меншинам тощо.

Зважаючи на сформовану класифікацію, можна здійснити диференціацію Міжнародного театрального фестивалю жіночих монодрам «Марія» за такими ознаками:

- організаційно-територіальним статусом - міжнародний;

- фаховим статусом - професійний;

- формою проведення - стаціонарний;

- місцем проведення - столичний;

- локацією - приміщення Національного академічного драматичного театру ім. Івана Франка;

- періодичністю - щорічний;

- тривалістю проведення - короткостроковий;

- форматом проведення - фестиваль моновистав;

- формою змагальності - фестиваль-репрезентація;

- жанрово-репертуарною палітрою - різножанровий;

- способом залучення глядача - благодійний;

- джерелами фінансування - державно-приватний;

- статевою та віковою ознакою - жіночий;

- іменним статусом - персоніфікований (присвячений Марії Заньковецькій).

В Україні діє низка міжнародних і всеукраїнських театральних фестивалів, кожен з яких має специфічні особливості. Серед них $є$ ще один фестиваль, названий на честь геніальної артистки, - Міжнародний театральний фестиваль жіночої творчості імені Марії Заньковецької, що відбувається в Ніжинському академічному українському драматичному театрі імені Михайла Коцюбинського. Він 
Bulletin of Kyiv National University of Culture and Arts

Series in Stage Art

є ровесником фестивалю «Марія», оскільки заснований також у 2004 р., однак не $є$ фестивалем моновистав.

Серед міжнародних фестивалів моновистав $є$ такі, як фестиваль монодрами «Solo Plays Fest» (Київ), фестиваль моновистав «Відлуння» (Хмельницький, Київ), фестиваль мономистецтв «Розкуття» (Хмельницький), фестиваль моновистав «Монологи над Ужем». З-поміж згаданих фестивалів Міжнародний фестиваль жіночих монодрам «Марія» посідає особливе місце, зважаючи на місце проведення, рівень фестивальних вистав і різноманітних заходів, благодійність, відсутність конкурсного відбору тощо. Вагомою конкурентною перевагою фестивалю $є$ те, що він відбувається в столиці, і до того ж на першій драматичній сцені України.

Відсутність конкурсного відбору, а відповідно й визначення переможців і переможених дає змогу учасникам фестивалю «Марія» зосередити свою увагу не на взаємному поборюванні, а на подоланні своїх комплексів, підвищенні акторської майстерності, встановленні дружніх стосунків. Деякі учасниці неодноразово беруть участь у фестивалі, а тому можна побачити динаміку їхнього творчого зростання. По суті, відбувається формування великої театральної багатонаціональної родини.

Організатори фестивалю декларують свою європейськість. Однак слід враховувати, що глобалізаційні процеси у світі, політика мультикультуралізму, поширення масової культури в країнах Європейського Співтовариства призводять до девальвації культурних цінностей, розмивання національної та культурної ідентичності корінного населення. Глобалізація має безпосередній вплив і на розвиток фестивального руху в європейських країнах. Так, аналіз літератури з питань організації фестивалів в країнах ЄС свідчить про те, що сучасні «європейські фестивалі мистецтв є важливим вираженням космополітичного настрою, що об'єднує митців та глядачів, яких цікавить різноманітність як знання, досвід та обмін» $(2014$, с. 15). Тож, використовуючи європейський фестивальний досвід, маємо враховувати той факт, що в Україні продовжується суспільно-політична криза, відбуваються бойові дії на східних теренах, триває пошук своєї національнокультурної ідентичності. Тому не всі європейські цінності, а тим більше космополітичні настрої, є для нас прийнятними.

Європейська асоціація фестивалів, що інтегрує понад 100 фестивалів і фестивальних об'єднань із більш ніж 40 країн світу, започаткувала у 2014 р. проєкт «Європапідтримує фестивалі, фестиваліпідтримують Європу» (EFFE). Відповідно в країнах-учасницях створено EFFE Хаби, що покликані заохочувати національні фестивалі до співпраці на європейському рівні, популяризувати їх за допомогою реєстрації на онлайн-порталі фестивалів, сприяти отриманню відзнаки якості EFFE. Конкурс проводять раз на два роки. Основними критеріями відбору фестивалів є «мистецька якість та інноваційний підхід, залучення місцевих громад, європейський і глобальний виміри» (Буценко, 2018). За результатами конкурсу 2019-2020 рр. 26 українських фестивалів здобули європейський «знак якості» EFFE лейбл. Серед них Міжнародний фестиваль монодрам «Solo Plays Fest». Водночас фестиваль «ГогольFEST» здобув нагороду EFFE Award, яку називають європейським фестивальним «Оскаром». На жаль, Міжнародний фестиваль жіночих монодрам «Марія» не брав участь у згаданому конкурсі. 
Вісник Київського національного університету культури і мистецтв.

Серія: Сценічне мистецтво

Важливо, хто представляє Україну на міжнародних театральних фестивалях за кордоном, оскільки ці репрезентанти формують не лише міжнародний імідж України, а й уявлення про її національне обличчя. Тож фестивалю «Марія» доцільно брати участь в європейському фестивальному русі та бути достойним репрезентантом українського театрального мистецтва.

Фестиваль - це не лише мистецький захід, а й важливий чинник міжкультурної комунікації. Поняття «міжкультурна комунікація» витлумачують як «особливу форму комунікації двох або більше представників різних культур, у процесі якої відбувається обмін інформацією і культурними цінностями взаємодіючих культур» (Садохін, 2005, с.95). Специфіка міжнародних театральних фестивалів полягає в тому, що для їх учасників і глядачів важливим $є$ навіть не так знання іноземної мови, як знання мови театру.

Діалогічність і полілогічність пронизують усі складові фестивалю «Марія», проявляючись у спілкуванні виконавиць моновистав з глядачами, доповідачів з аудиторією на науковій конференції та круглому столі, у дискусіях під час обговорення моновистав та проблем театрального мистецтва, у спілкуванні між собою учасників фестивалю тощо.

Нині продовження діяльності фестивалю - це вже навіть не справа однієї людини, а справа честі держави, індикатор розвитку в Україні театру одного актора, реалізація творчого потенціалу жінки-акторки, зміцнення її ролі в розвитку театрального мистецтва, у суспільному житті, презентація у світі українського театрального мистецтва. Зважаючи на унікальність фестивалю, доцільно фотографувати та здійснювати відеозаписи всіх вистав, наукових конференцій, круглих столів, інших значущих подій і створювати в музеї Національного академічного драматичного театру ім. Івана Франка фото- та відеотеки фестивалю.

Наукова новизна дослідження полягає в його системності, комплексності, здійсненні класифікації театральних фестивалів та ґрунтовному аналізі складових фестивалю «Марія», з'ясуванні його феномену.

\section{Висновки}

Отже, міжнародний театральний фестиваль жіночих монодрам «Марія» - єдиний в Європі жіночий фестиваль моновистав, територія діалогу та полілогу, успішного проєкту, який об'єднує мисткинь різних країн і різних культур, територія культурної дипломатії, наповнена певними смислами, енергіями. Репертуар фестивальних моновистав відзначається різножанровістю, високим професіоналізмом виконавців, сучасним режисерським прочитанням. Це організований на високому рівні щорічний культурно-мистецький форум, у межах якого відбуваються науково-творчі конференції та круглі столи, майстер-класи, тематичні виставки, творчі дискусії, презентації книг з теорії та історії театру. Фестиваль сприяє інтеграції українського театру до європейського культурного простору, надає глядачам змогу побачити кращі моновистави за участі українських і зарубіжних виконавців. Перспективним для теорії та практики сценічного мистецтва видається комплексне дослідження Міжнародного театрального фестивалю жіночих монодрам «Марія» на рівні монографії, де варто детально проаналізувати не лише організаційні питання, фестивальні моновистави, 
творчість провідних зарубіжних і українських акторок, які брали участь у фестивалі, а й результати науково-практичних конференцій та круглих столів.

\section{СПИСОК ПОСИЛАНЬ}

Бортнік, Ж.І., 2015. Монодрама як об'єкт теоретичної та критичної рефлексії: історія досліджень. Питання літературознавства, 91, с.123-136.

Буценко, О., 2018. EFA/EFFE ХАБ-Україна. Demcult. [online] Доступно: <http://demcult.org/ golovna/repertoire-2/> [Дата звернення 12 квітня 2021].

Гончаренко, Л., 2017. Фестиваль «Марія» продовжує культурний полілог. Голос України, 6 жовтня.

Евреинов, Н., 1909. Введение в монодраму. Издание И. Н. Бутковской. Санкт-Петербург. Кадирова, Л., 2013. Міжнародний театральний фестиваль жіночих монодрам «Марія». Науковий вісник Київського національного університету театру, кіно і телебачення імені І. К. Карпенка-Карого, 12, с.84-94.

Литовка, О., 2013. Фестивальний рух України періоду їі незалежності. Вісник КНУКіМ. Серія: Соціальні комунікації, 2, с.111-115.

Овчаренко, Е., 2019. Єдиний фестиваль в Європі. I-UA.tv. [online] 16 жовтня. Доступно: <https://i-ua.tv/culture/25787-yedynyi-festyval-u-yevropi> [Дата звернення 12 квітня 2021] Паві, П., 2006. Словник театру. Переклад з французької М. Якубяк. Львів: Львівський національний університет ім. І. Франка.

Підлужна, А., 2013. Щаслива самотність актриси. Лариса Кадирова. Харків.

Поліщук, Т., 2019. «Ми є і будемо жити»! Лариса Кадирова, художній керівник міжнародного фестивалю «Марія» - про повноліття форуму. День, 3 жовтня.

Садохин, А., 2005. Введение в теорию межкультурной коммуникации. Москва: Высшая школа.

Толошняк, Н.А., 2006. Монодрама. В: І.М. Дзюба, А.І. Жуковський та М.Г. Железняк, редкол. Енциклопедія Сучасної України. [online] Доступно: <http://esu.com.ua/search_articles. php?id=69179> [Дата звернення 12 квітня 2021].

Final Report Summary - EURO-FESTIVAL (Art Festivals and the European Public Culture), 2014 European Commission logo CORDIS EU research results. [online] Доступно: <https://cordis. europa.eu/project/id/215747/ reporting/de> [Дата звернення 12 квітня 2021].

\section{REFERENCES}

Bortnik, Zh.I., 2015. Monodrama yak obiekt teoretychnoi ta krytychnoi refleksii: istoriia doslidzhen [Monodrama as an object of theoretical and critical reflection: the history of research]. Pytannia literaturoznavstva, 91, pp.123-136.

Butsenko, O., 2018. EFA/EFFE KhAB-Ukraina [EFA / EFFE HUB-Ukraine]. Demcult. [online] Available at: <http://demcult.org/golovna/ repertoire-2/> [Accessed 12 April 2021].

Evreinov, N., 1909. Vvedenie $v$ monodramu [Introduction to monodrama]. Published by I. N. Butkovskaya. St. Petersburg.

Final Report Summary - EURO-FESTIVAL (Art Festivals and the European Public Culture), 2014. European Commission logo CORDIS EU research results. [online] Available at: <https://cordis. europa.eu/project/id/215747/reporting/de> [Accessed 12 April 2021]. 
Honcharenko, L., 2017. Festyval "Mariia" prodovzhuie kulturnyi poliloh [The festival "Mariia"continues the cultural polylogue]. Holos Ukrainy, 6 October.

Kadyrova, L., 2013. Mizhnarodnyi teatralnyi festyval zhinochykh monodram "Mariia" [International Theater Festival of Women Monodramas "Mariia"]. Academic Bulletin of Kyiv National Karpenko-Karyi University of Theatre, Cinema and Television, 12, pp.84-94.

Lytovka, O., 2013. Festyvalnyi rukh Ukrainy periodu yii nezalezhnosti [Festival movement of Ukraine during its independence]. Visnyk KNUKiM. Seriia: Sotsialni komunikatsii, 2, pp.111-115. Ovcharenko, E., 2019. Yedynyi festyval v Yevropi [The only festival in Europe]. I-UA.tv. [online] 160ctober.Availableat:<https://i-ua.tv/culture/25787-yedynyi-festyval-u-yevropi>[Accessed12April2021]. Pavi, P., 2006. Slovnyk teatru [Dictionary of theater]. Translated from French by M. Yakubyak. Lviv: Lvivskyi natsionalnyi universytet im. I. Franka.

Pidluzhna, A., 2013. Shchaslyva samotnist aktrysy. Larysa Kadyrova [Happy loneliness of the actress. Larisa Kadyrova]. Kharkiv.

Polishchuk, T.,2019.“Myyeibudemozhyty"! LarysaKadyrova,khudozhniikerivnykmizhnarodnoho festyvaliu "Mariia" - pro povnolittia forumu["We are and will live"! Larysa Kadyrova, artistic director of the international festival "Mariia" -about the coming of age of the forum]. Den, 3 October.

Sadokhin, A., 2005. Vvedenie $v$ teoriiu mezhkulturnoi kommunikatcii [Introduction to the theory of intercultural communication]. Moscow: Vysshaia shkola.

Toloshniak, N.A., 2006. Monodrama [Monodrama]. In: I.M. Dziuba, A.I. Zhukovskyi and M.H. Zhelezniak, eds. Encyclopedia of Modern Ukraine. [online] Available at: <http://esu.com. ua/search_articles.php?id=69179> [Accessed 12 April 2021].

\title{
МЕЖДУНАРОДНЫЙ ФЕСТИВАЛЬ ЖЕНСКИХ МОНОДРАМ «МАРИЯ» КАК ДИАЛОГ КУЛЬТУР
}

\section{Ольга Шлемко}

кандидат искусствоведения, доцент, заслуженная артистка Украины; e-mail: olgateren@ukr.net; ORCID: 0000-0002-3431-4521

Национальная академия руководящих кадров культуры и искусств, Киев, Украина

\begin{abstract}
Аннотация
Цель работы - выявить генезис и динамику современного развития Международного фестиваля женских монодрам «Мария», определить его место и роль в системе театрального фестивального движения Украины и Европейского Сообщества, выяснить специфику организационной, художественной и социокультурной составляющей фестиваля. Методология исследования заключается в применении системного, театроведческого и культурологического подходов, а также ряда методов: культурноисторического, классификации, проблемно-хронологического, наблюдения, сравнения. Научная новизна исследования заключается в его системности, комплексности, осуществлении классификации театральных фестивалей и основательном анализе составляющих фестиваля «Мария», выяснении его феномена. Выводы. Международный театральный фестиваль женских монодрам «Мария» - единственный в Европе
\end{abstract}


женский фестиваль моноспектаклей, территория диалога и полилога, успешного проекта, объединяющего актрис разных стран и разных культур, территория культурной дипломатии, наполненная определенными смыслами, энергиями. Репертуар фестивальных моноспектаклей отмечается разножанровостью, высоким профессионализмом исполнителей, современным режиссерским прочтением. Это организованный на высоком уровне ежегодный культурно-художественный форум, в рамках которого проходят научно-творческие конференции и круглые столы, мастерклассы, тематические выставки, творческие дискуссии, презентации книг по теории и истории театра. Фестиваль способствует интеграции украинского театра в европейское культурное пространство, предоставляет зрителям возможность увидеть лучшие моноспектакли с участием украинских и зарубежных исполнителей.

Ключевые слова: моноспектакль; монодрама; женский; актриса; фестиваль «Мария»; международный; Лариса Кадырова

\section{"MARIIA" INTERNATIONAL WOMEN MONODRAM FESTIVAL AS A DIALOGUE OF CULTURES}

\section{Olga Shlemko}

Ph.D. in Art Studies, Associate Professor, Honored Artist of Ukraine; e-mail: olgateren@ukr.net; ORCID: 0000-0002-3431-4521

National Academy of Cultural and Arts Management, Kyiv, Ukraine

\section{Abstract}

The purpose of the article is to identify the genesis and dynamics of modern development of the International Festival of Women Monodramas "Mariia", to determine its place and role in the system of theatrical festival movement of Ukraine and the European community, to find out the specifics of the organizational, artistic and socio-cultural component of the festival. The research methodology lies in the application of systematic, theatrical and cultural approaches, as well as a number of methods: cultural-historical, classification, problem-chronological, observation and comparison. The scientific novelty of research consists in its systematization, complexity and classification of theater festivals and thorough analysis of the components of the festival "Mariia", clarification of its phenomenon. Conclusions. "Mariia" International Monodrama Theater Festival is the only women monologue festival in Europe, a territory of dialogue and polylogue, a successful project that unites artists from different countries and different cultures, a territory of cultural diplomacy filled with certain meanings and energies. The repertoire of festival monoperformances is celebrated by diversity, high professionalism of performers, modern directorial reading. It is a high-level annual cultural and artistic forum, which includes scientific and creative conferences and round tables, workshops, thematic exhibitions, creative discussions, book presentations on the theory and history of theater. The festival promotes the integration of Ukrainian theater into the European cultural space, gives the audience the opportunity to see the best mono-performances with the participation of Ukrainian and foreign performers.

Keywords: monograph; monodrama; female; actress; "Mariia" Festival; international; Larysa Kadyrova 